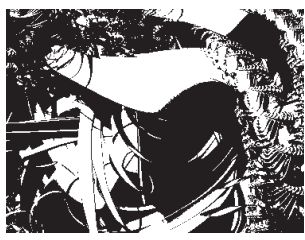

doi:10.5559/di.20.3.12

\title{
TERORIZAM U TEORIJAMA I TEORIJSKIM PERSPEKTIVAMA
}

Mirko BILANDŽIĆ

Filozofski fakultet, Zagreb

UDK: 316.285

323.28

Pregledni rad

Primlieno: 29. 3. 2010.

Terorizam je pojam oko kojeg u akademskim, stručnim, političkim i širim društvenim krugovima nije postignuta suglasnost u pogledu općeprihvaćenog, generičkog određenja. Unatoč tome, u cilju potpunijega razumijevanja terorizma, taj je fenomen korisno analizirati kroz prizmu teorija i teorijskih perspektiva. Rad donosi prikaz niza teorija moći i teorija sukoba te njihovu primjenu na teror, terorizam i terorističke organizacije, kao i na odnos terorističkih organizacija, kao nedržavnih entiteta, i država. Istaknutije mjesto u radu zauzima tzv. model triju stupova, kao sveobuhvatni teorijski pristup rješenju sukoba.

Ključne riječi: terorizam, teorije moći, meka moć, teorije sukoba, "model triju stupova", protuterorizam

$\triangle$ Mirko Bilandžić, Filozofski fakultet Sveučilišta u Zagrebu, Odsjek za sociologiju, I. Lučića 3, 10000 Zagreb, Hrvatska. E-mail: mbilandz@ffzg.hr

\section{UVOD}

Terorizam je na svjetskoj sceni više od dva stoljeća, u većem ili manjem opsegu, sastavni dio društvenih i političkih kretanja. Unatoč postojanju širokoga istraživačkog interesa, općeprihvaćena generička definicija terorizma nije postignuta. ${ }^{1}$ Time je terorizam ostao, još uvijek, do kraja neobjašnjen fenomen. Walter Laqueur tvrdi da generička definicija terorizma nije postignuta naprosto zato što nema definicije koja može potpuno pokriti sve inačice terorizma koje su se pojavile $u$ povijesti (Laqueur, 1987., 11). Njegova predviđanja izrečena još sredinom 1970-ih kako takva definicija neće biti postignuta ni u predvidljivoj budućnosti pokazala su se istinitima (Laqueur, 1977., 5-7). Walter Laquer je i predstavnik grupacije znan- 
DRUŠ. ISTRAŽ. ZAGREB GOD. 20 (2011) BR. $3(113)$

STR. 837-859

BILANDŽIĆ, $M$ TERORIZAM... stvenika koja smatra da se terorizam može znanstveno proučavati makar nije definiran (Laqueur, 1977., 3), za razliku u znanstvenika, poput Jacka Gibbsa, koji smatraju da znanstvena istraživanja zahtijevaju definiranje objekta istraživanja s elementima teorijskoga značenja i empirijske primjenjivosti (Gibbs, 1989.). Ovako suprotstavljena znanstvena i stručna stajališta opravdano nameću potrebu daljnjeg izučavanja terorizma, kao jedne od kontroverznijih tema društvenih znanosti oko koje postoji niz dilema i prijepora (Spencer, 2006.). Stoga je opravdano postaviti pitanje može li se jedan nedefiniran pojam promatrati u okviru teorija, teorijskih pristupa, koncepata i teorijskih modela? Cilj je ovoga rada razmotriti odnos terorizma i raznih teorija, pri čemu središte interesa nisu "teoretiziranja teorija" ni definicija terorizma shvaćenog kao uporaba nasilja (terora) radi ostvarenja političkih ciljeva (Schmid i Jongman, 1988., 5) nego prikaz terorizma kroz prizmu pojedinih teorijskih okvira.

\section{TEORIJE MOĆI I TERORIZAM}

Moć je sastavni element društvenih odnosa. Klasično realističko određenje moći, ono Maxa Webera, tvrdi da je moć sposobnost da se vlastitom voljom drugima nameće željeno ponašanje, to je vjerojatnost da će jedan akter tog odnosa ostvariti svoj cilj unatoč protivljenju drugih aktera (Giddens, 2007.; Haralambos i Holborn, 2002.; Galbraith, 1983.; Kalanj, 1994.; Novalić, 2005.; Svete, 2006.). ${ }^{2}$ Terorizam se sasvim sigurno uklapa u ovo određenje: uporabom nasilja (terora) drugima se nastoji nametnuti vlastita volja. Terorizam je vezan uz političke procese koje karakterizira nastojanje političkih aktera usmjereno na postizanje političkih promjena, ostvarenje vlasti, moći i dominacije. Kao politička strategija (Townshend, 2003., 5-14), terorizam je, s jedne strane, usmjeren na postizanje političkih promjena, osvajanje vlasti ili održavanje političkoga status quo, to je borba za moć i postizanje moći, dok je s druge strane i izraz moći. Na općoj razini, povijesno promatrano, možemo se osvrnuti na totalitarne državne sustave. Uporabom brutalnoga terora totalitarne su države svojoj volji podčinjavale široke slojeve stanovništva. Terorističke organizacije kao nedržavni entiteti također se bore za osvajanje vlasti i postizanje moći. Ubilačkom terorističkom kampanjom usmjerenom prema Ujedinjenom Kraljevstvu Irska republikanska armija (Irish Republican Army - IRA), kao predvodnik nasilnoga dijela sjevernoirskoga katoličkog korpusa, desetljećima nastoji ostvariti republikanski ideal: povrat slobode i stvaranje neovisne irske države na cjelokupnom teritoriju irskog otoka. Baskijska domovina i sloboda (engl. Basque Fatherland and Freedom; bask. Euskadi Ta Askatasuna - ETA) od trenutka nastanka 
DRUŠ. ISTRAŽ. ZAGREB GOD. 20 (2011), BR. 3 (113)

BILANDŽIĆ, M. TERORIZAM...
STR. $837-859$

1959. uporabom terora usmjerenog spram španjolskih vlasti nastoji stvoriti neovisnu i samostalnu baskijsku državu. Afrički nacionalni kongres (African National Congress - ANC) od početka 1960-ih terorom je nastojao srušiti službenu politiku aparthejda i osvojiti vlast u Južnoafričkoj Republici. U tome je i uspio na početku 1990-ih. Palestinska oslobodilačka organizacija (Palestine Liberation Organization - PLO) i njezina najvažnija teroristička organizacija, Fatah (ar. pobjeda), ili Pokret za oslobođenje Palestine (ar. Harakat al-Tahrir al-Vatanijja al-Filistinija), od sredine 1960-ih nastoje utjecati na izraelske vlasti i međunarodnu zajednicu kako bi Palestincima omogućili stvaranje palestinske države. Tim se nastojanjima potkraj 1980-ih pridružio i Islamski pokret otpora, po arapskom akronimu poznat kao Hamas (Harakat al Muqawama al Islamiyya). Niz islamističkih terorističkih organizacija, primjerice Egipatska islamska grupa (ar. al-Gama'at al-Islamiyya, engl. Islamic Group) i Oružana islamska grupa (ar. al-Jama'ah al-Islamiyah al-Musallaha, franc. Groupe Islamique Arme - GIA), već desetljećima terorom nastoje srušiti autoritarne sekularne režime u Egiptu i Alžiru, osvojiti vlast, a države organizirati u skladu s islamističkim (šerijatsko pravo) načelima.

\section{Kondigna, kompenzacijska i kondicionirana moć}

John Kenneth Galbraith (1983.) razlikuje tri vrste moći: kondigna, kompenzacijska i kondicionirana. Terorizam je socijalni konstrukt (Turk, 2004.) koji se u cijelosti ili pojedine njegove elemente može promatrati kroz svaku od tih kategorija. Kondigna moć povezana je s kažnjavanjem. Kompenzacijska moć onima koji se žele podčiniti nudi pozitivnu nagradu. Kod kondicionirane moći postupno se mijenjaju uvjerenja (vjerovanja) onih koje se želi podčiniti.

U razmatranju kondigne moći odnos države i terorističkih organizacija je isključiv. Svaka teroristička organizacija ima svoje političke ciljeve. Državama su takvi ciljevi često neprihvatljivi. Neprihvatljivost ciljeva usmjerava terorističke organizacije ka kažnjavanju država, i to uporabom nasilja (terora). Koji su razmjeri kažnjavanja, kakva je kondigna moć terorizma? Statistički podaci koji se odnose na razdoblje suvremenoga terorizma o tome sasvim dovoljno govore. Od kraja 1960-ih godina do danas diljem svijeta djeluje 648 terorističkih organizacija (Jones i Libicki, 2008.). U istom razdoblju u svijetu je izvršeno 80000 terorističkih akata (Dugan i dr., 2008.). Kondigna moć države također je izražena. U istom razdoblju države su kažnjavanjem, odnosno uporabom represije (policijsko-obavještajna i vojna djelovanja), uništile $47 \%$ terorističkih organizacija. S druge strane, pribjegavajući teroru (kažnjavanju), $10 \%$ terorističkih organizacija ostvarilo je svoje konačne ciljeve (Jones i Libicki, 2008.). 
DRUŠ. ISTRAŽ. ZAGREB GOD. 20 (2011) BR. $3(113)$

STR. 837-859

BILANDŽIĆ, $M$. TERORIZAM...
Kompenzacijska moć također je primjenjiva na odnos države i terorističkih organizacija. U zamjenu za apsolutno ili relativno prihvaćanje alternativnoga ponašanja oba aktera dobivaju nagrade. Riječ je o slučajevima kada terorističke organizacije odustaju od uporabe terora i uključuju se u legalne demokratske procese u pojedinoj državi te miroljubivim demokratskim putem nastoje ostvariti svoje ciljeve. U zamjenu za odustajanje od terora (nagrada državi) države (najčešće sklapanjem mirovnih sporazuma) omogućuju terorističkim organizacijama ulazak u legalnu i legitimnu politiku. S druge strane, terorističkim organizacijama nagrada je što im se ulaskom u legitimne političke procese priznaju njihovi ciljevi, koje sada nastoje ostvariti miroljubivim sredstvima. Riječ je o istim onim ciljevima zbog kojih su do jučer ubijali. U eri suvremenoga terorizma u $43 \%$ slučajeva terorističke organizacije odustale su od terora i uključile se u političke procese (Jones i Libicki, 2008.). U tim okvirima zanimljivo je analizirati slučaj "Privremene" Irske republikanske armije (Provisional Irish Republican Army - PIRA). ${ }^{3}$ Irski republikanski pokret od trenutka nastanka sredinom 19. stoljeća ima jedan cilj: oslobođenje od britanske vladavine i uspostavu neovisne Irske Republike. Nakon brutalnoga nasilja, koje je sjevernoirskom političkom i društvenom scenom dominiralo desetljećima, sjevernoirski mirovni pregovori kulminirali su povijesnim sporazumom sklopljenim na Veliki petak 10. travnja 1998. godine (Good Friday Agreement). Tim je činom završen 30-godišnji sjevernoirski sukob, sigurno jedan od najdugotrajnijih, najbrutalnijih i najkrvavijih sukoba u suvremenoj Europi, u kojem je živote izgubilo 3600 ljudi, dok ih je gotovo 50000 ranjeno. U zamjenu za odustajanje od terora britanska je vlada PIRA-i omogućila ulazak u političke procese. Odredba Sporazuma koja predviđa da će odluku o budućem ustavnom položaju Sjeverne Irske slobodno i demokratskim putem donijeti većina tamošnjega stanovništva, pri čemu takva odluka, uz isto tako izraženu suglasnost stanovništva u Republici Irskoj, može dovesti do ujedinjenja temelj je zbog kojeg su republikanci prihvatili Sporazum. Upravo je to cilj koji su do tada republikanci nastojali ostvariti terorom (Bilandžić, 2005.). ${ }^{4}$

Primjena kondicionirane moći na međusobni odnos države i terorističkih organizacija nema osobito značenje. Bilo kakvo međusobno kondicioniranje teško je primjenjivo. Analiza suvremenih političkih procesa ne upućuje na bilo kakve pozitivne efekte kondicioniranja na relaciji država - terorističke organizacije. No kondicionirana moć ima posebnu važnost kada se zasebno analiziraju terorističke organizacije. Organizacija se smatra najvažnijim izvorom moći (Lindblom, 1977., 26). Kondicionirana moć znači da iz organizacije, kao oblika 
DRUŠ. ISTRAŽ. ZAGREB GOD. 20 (2011), BR. 3 (113)

STR. 837-859

BILANDŽIĆ, M. TERORIZAM.. povezivanja ljudi sa sličnim interesima, vrednotama i shvaćanjima, izvire ono uvjeravanje koje je nužno za podčinjavanje ciljevima organizacije (Galbraith, 1983.).

Terorizam je uvjetovan socijalnim i političkim kontekstom. Teroristom se postaje kroz stanoviti proces "političke (re)socijalizacije". Potencijalni teroristi često počnu kao simpatizeri terorističke organizacije, potom počnu pružati pasivnu podršku, a s vremenom postaju njezini potpuno lojalni članovi. Da bi netko postao teroristom, trebaju biti zadovoljena tri uvjeta: motivacija pojedinca, prilika da se postane terorist i prihvatljivost pojedinca od strane terorističke organizacije koja kao ekskluzivna grupa odlučuje hoće li koga primiti u članstvo. Teroristička organizacija je organizacija sa socijalnim obilježjima (Hudson, 1999.). Nakon ulaska u terorističku organizaciju prema pojedincima se vrši pritisak prema punoj pripadnosti i postizanju konsenzusa u pogledu ciljeva organizacije. Unutar organizacije pojedincima se razvija osjećaj pripadnosti, osjećaj samopoštovanja i sustav uvjerenja kako bi teroristički čin smatrali prihvatljivim (dehumanizacija žrtava) u odnosu na konačne ciljeve (socijalni i politički učinci terora) terorističke organizacije koji su vrhovni (Stern, 2006.; Hamad, 2007.). O važnosti osjećaja pripadnosti dovoljno govori činjenica da pojedine terorističke organizacije činu učlanjenja pridaju ceremonijalna obilježja; ulazak, primjerice, u u Al Qa'idu radikalni islamisti diljem svijeta smatraju posebnom čašću $(\mathrm{Gu}-$ naratna, 2002., 8). Uostalom, pripadnici Al Qa'ide tajno polažu zakletvu osobno Osami bin Ladenu (Gerges, 2005., 36-37). Terorističke organizacije zahtijevaju totalnu posvećenost svojih članova organizaciji, reguliraju međusobne odnose, traže koheziju kroz međuovisnost i međusobno povjerenje i, nadasve, uvjeravaju svoje članove (indoktrinacija) u potpuno prihvaćanje ciljeva i načina djelovanja terorističke organizacije. $\mathrm{S}$ porastom radikalizacije grupni identitet nadilazi pojedinačni, teroristi individualni identitet podređuju kolektivnom, individualno prosuđivanje i ponašanje pod utjecajem je organizacije. Primjerice, prema pravilima Al Qa'ide, njezini članovi mogu izreći svoje mišljenje i čak utjecati na odluke čelnika. Te se odluke mogu i promijeniti ako tako odluči većina boraca. Na taj se način daje na važnosti borcima koji su snaga Al Qa'ide (Hamad, 2007.).

Terorističke organizacije posjeduju kondignu moć. One ne dopuštaju napuštanje, sankcije su stroge i okrutne, najčešće sa smrtnim ishodom. Primjerice, nizom Općih vojnih uredbi (General Army Orders) i "Zelenom knjigom" (Green Book: IRA Training Manual) PIRA je propisala sve elemente važne za funkcioniranje organizacije, kao i sankcije za prekršitelje pojedinih pravila ponašanja. Za kršenje bilo koje od propisanih 
DRUŠ. ISTRAŽ. ZAGREB GOD. 20 (2011) BR. $3(113)$

STR. 837-859

BILANDŽIĆ, $M$. TERORIZAM..

\section{Meka moć}

odredbi najblaža propisana kazna jest otpuštanje iz članstva, dok je za one najteže slučajeve (izdaja, krađa oružja PIRA-e) propisana smrtna kazna, koju, nakon izricanja od strane Vojnog suda, mora potvrditi Vojno vijeće (Bilandžić, 2005.). Kondicioniranje članstva terorističke organizacije, njegovo discipliniranje, reguliranje njegova ponašanja uz svladavanje opće i specijalizirane izobrazbe znači jačanje unutarnje snage terorističkih organizacija. John Kenneth Galbraith to naziva bimodalnom simetričnošću, što znači da organizacija može postići vanjske ciljeve samo ako je prethodno postigla podčinjavanje unutar same sebe. Jessica Stern $(2006 ., 167)$ ističe važnost otpornosti i sposobnosti terorističkih organizacija. Otpornost je snaga terorističke organizacije da podnese gubitke, dok je sposobnost mogućnost realizacije terorističkih napada. Učinkovitost terorističke organizacije rezultat je obaju obilježja. $\mathrm{O}$ važnosti bimodalne simetričnosti i otpornosti terorističkih organizacija u svojoj autobiografskoj knjizi "U mreži zla" uvjerljivo svjedoči Ali Hamad, bivši pripadnik Al Qa'ide. Prema Hamadu, Al Qa'ida posebnu pažnju posvećuje procesu socijalizacije kako bi zadržala ljude. Al Qa'ida se boji jedino udara iznutra, što znači da su članovi Al Qa'ide istodobno njezina najveća moć i najslabija točka. Istupanje ljudi iz Al Qa'ide, prema Hamadu, značilo bi da je njezin pristup pogrešan te da gubi svoju vrijednost i duhovni utjecaj. Drugim riječima, kondicionirana moć Al Qa'ide time bi bila dovedena u pitanje. S druge strane, Hamad ističe da je umiranje (žrtvovanje) članova Al Qa'ide dokaz da je njezin put ispravan. Stajališta bivšega člana Al Qa'ide sasvim su utemeljena. Dosadašnje nacionalne i međunarodne protuterorističke strategije nisu baš djelotvorne u borbi protiv terorizma. Stoga se nameće zaključak o potrebi ponovnoga promišljanja i razmatranju opcija za uključivanje elemenata kompenzacijske i, posebno, kondicionirane moći u buduće protuterorističke strategije. Amnestija i nastojanja za pridobijanjem članova Al Qa'ide za izlazak iz vodeće organizacije džihadističkoga pokreta potencijalno se čine efikasnim protuterorističkim mjerama.

Moć je jedan od središnjih pojmova međunarodnih odnosa. No za razliku od prijašnjega razdoblja i dominacije jednostranoga shvaćanja moći baziranog na sili, zadnja dva desetljeća u međunarodnim odnosima učestalo se govori o dva oblika moći: tvrdoj moći (hard power) i mekoj moći (soft power). Veza između tih dvaju pojmova jest ta što su to dva aspekta sposobnosti da se postignu određeni ciljevi utjecajem na ponašanje drugih. Pojam meke moći veže se uz harvardskoga profesora Josepha Nyea. ${ }^{5}$ 
DRUŠ. ISTRAŽ. ZAGREB GOD. 20 (2011), BR. $3(113)$

STR. 837-859

BILANDŽIĆ, M. TERORIZAM..
Analizom se mogu pronaći zajednički elementi kondicionirane i meke moći. No meka moć ipak je zaseban teorijski okvir. Meka moć je sposobnost dobivanja onoga što se želi posredstvom atraktivnosti, a ne prisile ili plaćanja. Ona izrasta iz atraktivnosti države, odnosno njezine kulture, političkih ideala, političkih vrijednosti i provedbe legitimnih politika. Joseph Nye meku moć definira kao sposobnost uvjeravanja drugih da žele što vi želite. Nepobitno je da države dio ciljeva ostvaruju ili mogu ostvariti isključivo prisilom. No postoje i ciljevi koji se mogu postići posredstvom "drugog lica moći" (the second face of power), ${ }^{6}$ odnosno meke moći. Država može postići rezultate koje želi u svjetskoj politici zato što je druge države žele slijediti, dive se njezinim vrijednostima, oponašaju njezin primjer i teže njezinoj razini napretka i otvorenosti. U tom je slučaju važno postaviti agendu prema kojoj će države drugima na svjetskoj sceni biti atraktivne, a ne prisiljavati druge na promjene prijetnjom uporabe vojnih snaga ili gospodarskih sankcija. Meka moć počiva na sposobnosti oblikovanja preferencija drugih. To je jednostavno sposobnost pridobivanja drugih da žele isto što i vi, a ne prisiljavanja drugih da čine ono što vi želite. Ona ima efekt širenja stvarajući opći utjecaj, za razliku od tvrde moći, koja proizvodi specifičnu akciju. Meka se moć ne može poistovjetiti isključivo s utjecajem, iako ona predstavlja jedan od izvora utjecaja, jer utjecaj može biti postignut i prijetnjama i nagradama. Meka je moć više i od persuazije ili pokretanja ljudi snagom argumenata. To je sposobnost postizanja atraktivnosti koja vodi do pristanaka za nešto ili nekoga (Nye, 2010.).

Koncept meke moći primjenjiv je na terorizam. Joseph Nye utemeljeno tvrdi da terorističke organizacije posjeduju i tvrdu i meku moć. Tvrda moć je nasilje, odnosno teror. Meka moć terorističkih organizacija jest njihova sposobnost dobivanja onoga što žele privlačenjem pažnje, a ne upotrebom sile. ${ }^{7}$ To je borba za srce i dušu. Ostvarenje ciljeva terorističkih organizacija i terorizma u jednakoj mjeri ovisi o mekoj moći, o sposobnosti pridobivanja podrške širih masa, kao i o njihovim nasilnim kapacitetima. Meka moć terorizma u suprotnosti je s onim s čim se terorizam poistovjećuje (teror). No meka moć ima iste efekte kao i nasilje odnosno sposobnost uništenja drugih od strane terorističkih organizacija. (Furedi, 2009., 224; Nye, 2010.). Posredstvom meke moći terorističke organizacije pridobivaju podršku širih masa iz kojih novače nove članove. Al Qa'ida ima snažnu meku i tvrdu moć. Ukupno, ta globalna mreža s ćelijama u 60-ak država, s više od 100000 vojno osposobljenih članova i 6-7 milijuna simpatizera (Gunaratna, 2002.; Sageman, 2004.; Stern, 2006; Offman, 2007.), ne samo da je jedan od najznačajnijih sigurnosnih izazova su- 
DRUŠ. ISTRAŽ. ZAGREB GOD. 20 (2011) BR. $3(113)$

STR. 837-859

BILANDŽIĆ, $M$ TERORIZAM... vremenoga svijeta nego nesumnjivo i subjekt međunarodnih odnosa $^{8}$ i globalne politike.

Kakav je odgovor svjetske zajednice na terorizam i jačanje moći terorističkih organizacija? Nakon brutalnog udara na SAD 11. rujna 2001. međunarodna zajednica pod američkim vodstvom naglasak je stavila na silu. Meka je moć kao protuteroristički odgovor zanemarena. Bio je to pogrešan pristup. Amerikanci su vojnim akcijama srušili režime u Afganistanu i Iraku, ali nisu spriječili terorizam. Štoviše, Al Qa'ida je danas jača nego dosad (Bilandžić, 2008.a, b). Stoga je očito došlo vrijeme za definiranje novih protuterorističkih nacionalnih i međunarodnih strategija. Aspekte meke moći nove bi strategije svakako trebale akceptirati. Razlog je vrlo jednostavan: Al Qa'ida uživa popularnost i podršku u nizu islamskih država. Istraživanje koje su stručnjaci University of Maryland proveli potkraj 2006. i na početku 2007. to jasno potvrđuje. Istraživanje stavova $\mathrm{u}$ odnosu na međunarodnu politiku (Program on International Policy Attitudes) objavljeno je u travnju 2007., a obuhvaćalo je istraživanje stavova u četiri države: Maroku, Egiptu, Pakistanu i Indoneziji. Istraživanje je pokazalo kako stanovništvo navedenih država u rasponu od 73\% (Indonezija) do $92 \%$ (Egipat) smatra da je cilj SAD-a oslabiti i podijeliti islamski svijet. Taj cilj, uz ostvarenje dominacije na Bliskom i Srednjem istoku, po njihovu mišljenju ima i američki "rat protiv terora". Raspon takvih stajališta kreće se od 53\% u Indoneziji do 86\% u Egiptu. Nadalje, 91\% Egipćana, 68\% Marokanaca, 36\% Pakistanaca i 30\% Indonežana opravdava terorističke udare na američke ciljeve na Bliskom i Srednjem istoku. Prema rezultatima istraživanja, u Maroku i Egiptu 70\% stanovništva opravdava samoubilačke akte, $38 \%$ stanovništva (prosjek) u 4 države ima negativne stavove prema SAD-u, dok 15\% njih opravdava terorističke akte na Amerikance diljem svijeta. Posebno je znakovito da u Egiptu 56\%, stanovništva, u Indoneziji 39\%, u Maroku 30\% te u Pakistanu 16\% stanovništva podržava Al Qa'idine akcije ili stajališta prema SAD-u, dok pozitivne stavove prema Osami bin Ladenu ima 40\% ljudi u Egiptu, 27\% u Maroku, 27\% u Pakistanu i 21\% u Indoneziji (Muslim Public Opinion on US Policy, 2007.). Premda izražena stajališta ne znače i konkretnu akciju, rezultati ovih istraživanja trebali bi zabrinuti suvremeni svijet. Nemogućnost dijela muslimanskoga svijeta da iz niza razloga ostvari svoje političke ciljeve miroljubivim sredstvima, izloženost poniženjima i kršenju ljudskih prava zamjetnoga dijela muslimanske populacije, represija kojoj je dio muslimanskoga stanovništva izložen u matičnim državama, neimaština i bijeda dijela muslimanske populacije i nejednakost u raspodjeli bogatstva, razne (i instrumentalizirane) interpretacije is- 
DRUŠ. ISTRAŽ. ZAGREB GOD. 20 (2011), BR. 3 (113)

STR. 837-859 TERORIZAM...
BILANDŽIĆ, $M$

lama i džihada, nezadovoljstvo lošom vladavinom u matičnim državama, osjećaj ugroženosti i nezadovoljstvo globalnim previranjima na međunarodnoj političkoj sceni te protuamerikanizam - sve su faktori koji kontinuirano pridonose kadrovskom te funkcionalno-organizacijskom obnavljanju terorističkih organizacija u islamskom svijetu, a time i Al Qa'ide. Kontinuirani pozivi Osame bin Ladena muslimanskoj populaciji da se pridruži Al Qa'idi, populaciji koja se osjeća nezadovoljno, obespravljeno i poniženo, unutar osjetnoga dijela te populacije još uvijek nailaze na plodno tlo. Džihadistički pokret na čelu s Al Q'idom ima, a očito će imati i ubuduće, zamjetan broj pristaša. Stoga je za njegovo iskorjenjivanje, iskorjenjivanje terorizma kojemu je posvećen ili pak sprječavanje njegovih učinaka, u budućim protuterorističkim strategijama nužno posvetiti pažnju primjeni koncepta meke moći i eliminiranju uzroka koji u islamskom svijetu uvjetuju terorizam.

\section{TEORIJE SUKOBA I TERORIZAM}

Terorizam je izraz krize, izraz društvenih proturječnosti i nezadovoljstva političkim i socijalnim kretanjima, ali i izraz različitih i suprotstavljenih interesa. Polazeći s tih stajališta, terorizam se može promatrati kroz razne perspektive sukoba. Sukob pritom podrazumijeva međusobno djelovanje suprotstavljenih strana, koje su zbog nastojanja ostvarenja vlastitih, a međusobno različitih, interesa i ciljeva usmjerene na zauzimanje superiornijega položaja i nanošenje poraza suprotstavljenoj strani. Teorije sukoba polaze sa stajališta postojanja fundamentalnih razlika u interesima između društvenih skupina koje rezultiraju sukobom, što je uobičajena i trajna odlika društva (Haralambos i Holborn, 2002., 11). James E. Dougherty i Robert L. Pfaltzgraff (1981., 187) stoje na stajalištu da su znanstvenici na području društvenih znanosti podijeljeni oko pitanja treba li društveni sukob promatrati kao nešto racionalno, konstruktivno i društveno funkcionalno ili kao nešto iracionalno, patološko i društveno disfunkcionalno. Znanstvenici i teoretičari kojima je istraživanje sukoba u središtu interesa do sada nisu utvrdili generičku teoriju sukoba. Sandra Cheldelin, Daniel Druckman i Larissa Fast (2003.) polaze sa stajališta da problematika rješenja sukoba obuhvaća teoretski okvir, istraživačke dosege i praktično djelovanje. U tim okvirima, poštujući dosadašnja znanstvena dostignuća i empirijske spoznaje, ponudili su generički okvir, odnosno kontekst, sukoba (Slika 1), koji je krucijalan element analize sukoba. Promatrajući sukobe kroz koncentrične krugove i valovite linije koje prodiru u te krugove, ističu da je unutarnji krug srž anali- 
DRUŠ. ISTRAŽ. ZAGREB GOD. 20 (2011) BR. $3(113)$

STR. 837-859

BILANDŽIĆ, $M$ TERORIZAM..

SLIKA 1

Opći kontekst sukoba: od analize sukoba do intervenciije izvore sukoba, tip sukoba i njegovu dinamiku. Drugi krug, "utjecaj i kontekst", analizira uvjete koji utječu na izbor djelovanja u sukobu te kontekst dinamike razvoja sukoba. Središnje točke toga kruga jesu kulturološki utjecaji na sukob i njegovo rješenje, lokalne i globalne strukture unutar kojih se sukob događa i rješava te legalne institucije kroz koje se posreduje sukob i njegovo rješenje. Ta dva kruga određuju izbor mehanizama i instrumenata za intervenciju u sukob, kao i njihovu efikasnost. Spektar instrumenata za intervenciju (nije linearna) u sukob vrlo je širok, a može ih se podijeliti u dvije kategorije. Prva su intervencije samih aktera sukoba posredstvom pregovora i njihovom sposobnošću postizanja sporazuma. Drugu kategoriju čini niz neformalnih, formalnih i sustavnih intervencija "treće strane" u sukob (pogodovanje, davanje olakšica, konzultacije, posredovanje, arbitraža, peace-building akcije itd.).

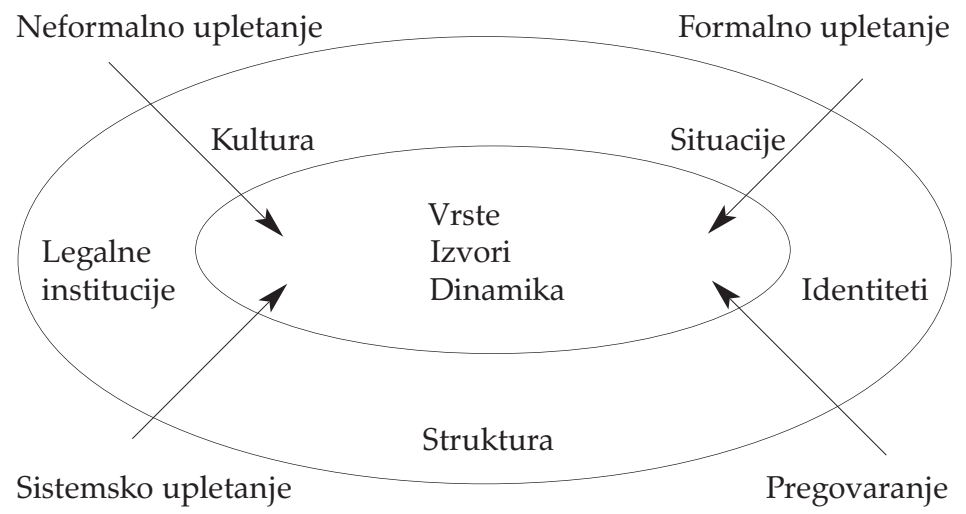

Izvor: Cheldelin i dr., 2003., 6

Nepostojanje općeprihaćene teorije sukoba ostavlja prostor za promatranje sukoba s različitih motrišta i određenje sukoba s obzirom na njihov različit uzrok, karakter i prirodu, modele za rješenja sukoba itd. ${ }^{9}$ Unatoč osjetnim razlikama među perspektivama i teorijama sukoba, sve one imaju jedan zajednički element: moć i uporabu moći.

Analiza sadržaja teorija ili promišljanja sukoba ima ne samo teoretsku važnost, već i važnost u pogledu praktične primjene na terorizam kao oblik sukoba. Najmanje su četiri razloga koja to dokazuju:

1. pružanje mogućnosti za utvrđivanje uzroka sukoba

2. pružanje mogućnosti za utvrđivanje prirode odnosno karaktera sukoba

3. stvaranje uvjeta za oblikovanje modela za objašnjenje sukoba

4. stvaranje pretpostavki za rješenje sukoba. 


\section{Realistični i nerealistični sukobi}

Lewis A. Coser (1969.) sukobe dijeli na realistične (realistic) i nerealistične (nonrealistic). Socijalne sukobe koji u određenom društvenom odnosu dvaju subjekata proizlaze iz frustracije zbog specifičnih zahtjeva koji su izravno usmjereni prema izvoru frustracija (druga strana u sukobu) te procjene sudionika da su takvi zahtjevi ostvarivi (ostvarenje pobjede u sukobu) Coser naziva realističnim sukobima. Riječ je zapravo o situaciji u kojoj je sukob sredstvo za ostvarenje cilja. Realistični sukobi podrazumijevaju uporabu raznih sredstava za ostvarenje cilja. Nerealistični sukobi jesu pak oni u kojima dolazi do oslobađanja tenzija strana u sukobu i nisu usmjereni na ostvarenje konkretnoga krajnjeg cilja. Riječ je o slučajevima kada su sukobi sami sebi svrha. Za razliku od realističnih sukoba, kod kojih postoje alternative za ostvarenje cilja, kod nerealističnih postoje alternativni objekti za usmjerenje tenzija. Slučaj Al Qa'ide zasigurno je pogodan primjer za primjenu shvaćanja Lewisa Cosera na terorizam. Analizom četiriju (1992.; 1996.; 1998.; 2001.) fetvi (fatwa $)^{10}$ kojima je Osama bin Laden pozvao na sveti rat mogu se zbrojiti ciljevi Al Qa'ide. To su: ujedinjenje muslimanskoga svijeta u borbi protiv SAD-a i njegovih saveznika; rušenje sekularnih i prozapadnih režima u muslimanskim državama na Bliskom/Srednjem istoku te stvaranje panislamističkoga kalifata, odnosno svjetske muslimanske države/ume (Jones i Libicki, 2008., xv). Analizom ciljeva dolazi se do zaključka da sukob $\mathrm{Al}$ Qa'ide i međunarodne zajednice predvođene SAD-om ulazi u okvire i realističnih i nerealističnih sukoba. No analiza praktičnih sociopolitičkih učinaka Al Qa'ide upućuje na drugačiji zaključak: ni jedan cilj Al Qa'ida do sada nije ostvarila. Ako se i prihvati mogućnost ostvarenja prvih dvaju ciljeva, treći je cilj Al Qa'ide $\mathrm{u}$ okvirima realpolitičkih trendova zasigurno neostvariv. U tom slučaju sukob Al Qa'ide i međunarodne zajednice predvođene SAD-om ulazi u okvire nerealističnih sukoba, sukoba u kojem je ubilačka teroristička kampanja Al Qa'ide sama sebi svrha.

Ovim teoretskim modelom mogu se analizirati dosezi sjevernoirskoga, bliskoistočnoga te španjolsko/francusko-baskijskoga sukoba, u kojima je, u njihovoj suvremenoj fazi od 1960-ih, terorizam u središtu sukoba. Palestinske terorističke organizacije uporabom terorizma nisu uspjele ostvariti svoj cilj: stvoriti neovisnu palestinsku državu. U tim nastojanjima nije uspjela ni ETA. U ostvarenju svojega cilja - uspostave neovisne irske države na teritoriju cjelokupnoga irskog otoka za sada nije uspješna ni PIRA. Premda je, ukupno promatrano, riječ o realističnim sukobima, izdvojeno promatranje ostvarenja ciljeva pokazuje da je riječ o nerealističnim sukobima. 
DRUŠ. ISTRAŽ. ZAGREB GOD. 20 (2011) BR. $3(113)$

STR. 837-859

BILANDŽIĆ, $M$. TERORIZAM...
Ako se zaključak o neostvarenju ciljeva palestinskih i (sjeverno)irskih terorističkih organizacija poveže s činjenicom da su sjevernoirski i bliskoistočni sukob izrazito složeni sukobi u kojima su ciljevi i dalje postojani, oba sukoba možemo svrstati u tip sukoba koji je Edward E. Azar sa suradnicima (Marshall, 1999., 134-135) nazvao "produljeni društveni sukob" (Protracted Social Conflict). Riječ je o dugotrajnim sukobima s velikim ulozima, u kojima sudjeluju cjelokupna društva (i s elementima ratovanja), pri čemu sukob djeluje kao faktor socijalnog identiteta i solidarnosti. Ti sukobi nisu pojedinačni događaji niti su skup događaja, nego su zapravo procesi. Po Azarovu mišljenju (1990.), ovaj sukob nastaje kada u nekom društvu postoje različite skupine (religijske, etničke, nacionalne, kulturne itd.) koje nastoje ostvariti i osigurati svoj zasebni identitet. Ako jedna skupina unutar društva ne može ostvariti ekonomsku sigurnost, onemogućena je u sudjelovanju u političkom procesu, fizički je ugrožena ili je druga skupina ne priznaje, dolazi do gubitka njezina zasebnog identiteta, koji ona nastoji povratiti čineći sve što je u njezinoj moći. Drugačije kazano, riječ je o tvrdokornim sukobima za koje nije lako pronaći rješenje, a pitanje je jesu li uopće i rješivi.

\section{Teorija riešenja sukoba}

Teorija rješenja sukoba (Conflict Resolution Theory) veže se uz ime profesora Johna Burtona (Burton, 2001.). Riječ je o holističkom pristupu duboko ukorijenjenim sukobima i pokušaju njihova trajnog rješenja, koje uključuje multidisciplinarna područja djelovanja: političko, socijalno, religijsko, pravno, kulturološko, povijesno, ekonomsko, komunikacijsko, sociopsihološko itd. Kao pragmatičan pristup, teorija rješenja sukoba usmjerena je na stvaranje multidimenzionalnoga procesa koji uključuje razne aktere, pitanja, norme i okvire za razumijevanje sukoba. Analizom subjektivnih i objektivnih aspekata sukoba teorija je usmjerena na rješenje sukoba. Podrazumijeva dugotrajan proces, koji se može podijeliti u tri faze: stvaranje uvjeta za postizanje sporazuma između sukobljenih strana, postizanje sporazuma i provedba sporazuma. Ova se teorija naslanja na teoriju ljudskih potreba (Human Needs Theory), koja tvrdi da postoje temeljne ljudske potrebe univerzalnoga karaktera (primjerice, ostvarenje sigurnosti, priznanje identiteta, mogućnost razvoja), čije zadovoljenje može eliminirati isključive zasebne ciljeve i time dovesti do rješenja sukoba. Zadovoljenje tih temeljnih ljudskih potreba uvjet je razvoja i stabilnosti društva (Vayrynen, 2010.). U protivnom, ako su pojedinci kao pripadnici društvenih skupina od strane vlasti, raznih elita ili drugih društvenih skupina onemogućeni u ostvarenju svojih potreba, društvena nestabilnost i sukob 
DRUŠ. ISTRAŽ. ZAGREB GOD. 20 (2011), BR. $3(113)$

STR. $837-859$

BILANDŽIĆ, M. TERORIZAM.. su neizbježni. Zadatak je teorije rješenja sukoba kreirati društvenu okolinu u kojoj će temeljne ljudske potrebe biti zadovoljene. Time bi se sukob transformirao iz okvira igre s "nultim rezultatom" (zero sum game) u okvir u kojem nema pobjednika i gubitnika, nego u kojem svi pobjeđuju (non-zero sum game/win-win game). Teorija rješenja sukoba podrazumijeva dugotrajni proces u kojem je potrebno provesti političke, ekonomske, institucionalne i socijalne reforme kako bi se stvorio novi državno-društveni okvir unutar kojeg bi temeljne ljudske potrebe mogle biti zadovoljene. Pritom je važno razriješiti i međugrupni sukob, što je zadatak "diplomacije na dva kolosijeka" (Track Two Diplomacy). To podrazumijeva sudjelovanje službene diplomacije (prvi kolosijek) i predstavnika sukobljenih grupa (drugi kolosijek), čiji međusobni kontakti uz pomoć posrednika trebaju dovesti do promjene percepcije sukoba, promjena stavova članova njihovih grupa prema drugoj grupi i sukobu te razvijanju ekonomske suradnje (Cunningham, 1998.).

Kakve su mogućnosti i rezultati primjene teorije rješenja sukoba na terorizam? Prije svega, očito je kako teorija rješenja sukoba nije usmjerena na eliminaciju sukoba nego na njegovu transformaciju u miroljubiv nenasilni proces socijalnih i političkih promjena (Miall i dr., 2005., 25). Time su sadržaji i ciljevi teorije rješenja sukoba vremenski nedefinirane kategorije. Sjevernoirski sukob, u kojem je terorizam središnji element, jedan je od najdugotrajnijih, najkrvavijih i najtvrdokornijih sukoba na svijetu. Sporazumom sklopljenim (uz američko posredovanje) na Veliki petak, 10. travnja 1998. (Good Friday Agreement), u Sjevernoj Irskoj je nakon 30 godina nasilja nastupio relativan mir. Analitičkim pristupom uočava se da je Sporazum na Veliki petak nastao kao sublimat uvjeta i instrumenata iz teorije rješenja sukoba. Sporazum je priznao da svi sudionici sukoba imaju legitimne potrebe koje moraju biti zadovoljene kako bi se sukob mogao riješiti. Njihovo zadovoljenje može se ostvariti institucionalnim promjenama i stvaranjem novih institucija u političkom, socijalnom i gospodarskom području, što zapravo podrazumijeva stvaranje novoga državno-političkog okvira. Također se uočava da je Sporazum postignut primjenom tzv. "diplomacije na dva kolosijeka" (Track Two Diplomacy) kao središnjeg instrumenta "teorije rješenja sukoba". Drugo, Sporazum je postavio sasvim drugačiji model vlasti u Sjevernoj Irskoj od onoga na razini Ujedinjenoga Kraljevstva. Na unutarnjoj razini ustanovljen je konsocijativni model, koji podrazumijeva podjelu vlasti između katolika i protestanata, umjesto dotadašnje dominacije protestanata. Treće, sadržajno promatrano, Sporazum je rezultat umjerenoga političkog pristupa problemu i on nudi primjeren okvir 
DRUŠ. ISTRAŽ. ZAGREB GOD. 20 (2011) BR. $3(113)$

STR. 837-859

BILANDŽIĆ, $M$ TERORIZAM.. svim stranama za postizanje ciljeva nenasilnim sredstvima: unionistima da Sjeverna Irska ostane dio Ujedinjenoga Kraljevstva, a republikancima da stvore jedinstvenu irsku državu. Teorija rješenja sukoba adekvatan je okvir koji je, s različitim uspjehom, primijenjen i na ostale sukobe koje u bitnoj mjeri obilježava terorizam: rješenje pitanja aparthejda u Južnoafričkoj Republici, rješavanje baskijskoga pitanja u Španjolskoj, palestinsko-izraelski sukob, izraelsko-libanonski sukob.

\section{Model triju stupova}

Utemeljitelj teorijskoga pristupa sukobu, poznatog kao "model/okvir triju stupova" (Three Pillar Framework) jest Dennis Sandole, profesor na Institute for Conflict Analysis and Resolution, George Mason University. Riječ je o modelu (Slika 2) koji predstavlja teorijski okvir za analizu i rješenje bilo kojeg sukoba u bilo kojoj dinamičkoj fazi. U analizi sukoba Dennis Sandole polazi od same dinamike. Sukob ima nekoliko faza: začeci sukoba (initiation), eskalacija sukoba (escalation), kontrolirano zadržavanje sukoba i sprječavanje njegova širenja (controlled maintenance), možebitno popuštanje sukoba (de-escalation) i završetak sukoba (termination). Sandole nadalje razlikuje latentne sukobe (latent conflicts - preMCPs), manifestne procesne sukobe (manifest conflict processes - MCPs) i agresivno manifestne procesne sukobe (aggressive manifest conflict processes - AMCP). Latentni sukobi jesu sukobi u nastajanju, MCPs sukobi jesu sukobi u kojima je nasilje već izraženo, dok su AMCP sukobi oni kod kojih je nasilje tako izraženo da mo-

(1) SLIKA 2 že imati destruktivne učinke za strane u sukobu (Sandole i van Model triju stupova der Merwe, 1993.; Sandole, 1998., 2003., 2004.).

\begin{tabular}{lll}
\hline Stup 2 & Stup 1 & Stup 3 \\
\hline Uzroci i uvjeti & Sukob & Intervencije u sukobe \\
nastajanja sukoba & [Latentni (pre-MCP) MCP/AMCP] & Ciljevi treće strane \\
Osobna razina & Organizacije [nasilne] & Prevencija sukoba (Prevention) \\
Društvena razina & Problemi & Upravljanje sukobom \\
Međunarodna razina & Ciljevi & Izravnavanje sukoba \\
Globalna/ekološka razina & Značenja & Rješenje sukoba \\
& Upravljanje sukobima & Transformacija sukoba \\
& Orijentacije & (Prevencija sukoba - \\
& Sukob & Provention) \\
& Okolina & Pristupi treće strane \\
& & Kompetitivni i/ili kooperativni \\
& & procesi \\
& & Negativne i/ili pozitivne ori- \\
& jentacije prema miru \\
& & Track-1 i/ili Track-2 uloge \\
& & i procesi \\
\hline
\end{tabular}

Izvor: Sandole, 2003., 43 
DRUŠ. ISTRAŽ. ZAGREB GOD. 20 (2011), BR. 3 (113)

STR. $837-859$

BILANDŽIĆ, M. TERORIZAM..
Prvi je stup usredotočen na elemente sukoba (conflict elements), što uključuje aktere sukoba, pitanja zbog kojih su suprotstavljene strane sukobljene, ciljeve sukoba, sredstva koja se primjenjuju u sukobu (miroljubiva ili nasilna), orijentacije aktera sukoba u pogledu usmjeravanja sukoba (izbjegavanje sukoba, konfrontacija, kompromis, prostor društvene okoline u kojoj se sukob događa promatran s povijesnog aspekta, političkog aspekta, socijalnog, religijskog, institucionalnog aspekta itd.).

Drugi stup analizira uzroke sukoba i uvjete sukoba (conflict causes and conditions) koji imaju operativnu dimenziju na različitim razinama, koje su predmet interesa raznih znanosti i ekspertiza: a) individualna razina - fiziologija, biologija, psihologija, psihijatrija, teologija; b) socijetalna razina - sociologija, povijest, politologija, antropologija, ekonomija; c) međunarodna razina - specijalisti sa socijetalne razine te diplomacija i međunarodni odnosi; d) globalna razina/ razina ekologije - demografija, ekologija, geologija. ${ }^{11}$ Treći je stup usredotočen na intervencije "treće strane" (third party intervention) u sukobu. Intervencije se promatraju kroz dvije kategorije: ciljeve intervencije i sredstva/pristupe intervencije u sukobu. Ciljevi intervencije uključuju: a) prevenciju sukoba (conflict prevention), b) upravljanje sukobom (conflict management), c) "izravnavanje" sukoba (conflict settlement), $12 \mathrm{~d}$ ) rješenje sukoba (conflict resolution) i stvaranje uvjeta "negativnoga mira" (odsutnost nasilja) i e) transformaciju sukoba (conflict transformation), ${ }^{13}$ odnosno stvaranje "pozitivnoga mira". Sredstva, odnosno pristupi, intervencijama jesu: a) konfrontacijski (confrontational) ili suradnički (collaborative) pristup, b) pristup "negativnoga" (odsutnost nasilja) ili "pozitivnoga" (eliminacija uzroka sukoba) mira i c) uporaba službene (track 1 diplomacy) i neslužbene (multi-track diplomacy) nacionalne i međunarodne diplomacije. Zaključno, "model/okvir triju stupova" jest teorijski pristup koji smatra da je sukob na bilo kojoj razini (stup 1) kompleksan prema svojoj etiologiji (stup 2), zbog čega se za njegovo rješavanje također zahtijeva sveobuhvatan i kompleksan pristup (stup 3).

Kakvi su dosezi primjene "modela triju stupova" na analizu problematike terorizma i rješavanja pitanja terorizma? ${ }^{14}$ Prethodno je istaknuto da je terorizam fenomen koji se generira iz političkoga područja. Analiza procesa terorizma pokazuje da ima tri temeljna elementa:

1. uzroke koji dovode do političkoga nasilja koje prerasta $\mathrm{u}$ terorizam; 2 . terorističke akte koje najčešće izvode terorističke organizacije, ali nerijetko i države te 3 . protuteroristič$\mathrm{ku}$ politiku, odnosno protuterorističko djelovanje.

Dosadašnji model borbe protiv terorizma nije donio rezultat. Nacionalne i međunarodne protuterorističke strategije neefikasne su. Razlog je vrlo jednostavan: usredotočene su is- 
DRUŠ. ISTRAŽ. ZAGREB BR. $3(113)$

STR. 837-859

BILANDŽIĆ, $M$. TERORIZAM... GOD. 20 (2011),

ključivo na sprječavanje izvođenja budućih terorističkih akata, a ne na eliminaciju i iskorjenjivanje terorizma. Stoga je očito riječ o strategijama za borbu protiv terora, a ne terorizma. Njihovo oslanjanje na realpolitičku primjenu sile kao sredstva za eliminaciju terorizma nije efikasan pristup. Ako se u kontekstu protuterorističkih strategija terorizam shvati u potpunosti, tj. sa svim elementima svoje strukture, sasvim je jasno da je najefikasnije sredstvo za eliminiranje terorizma otklanjanje njegovih uzroka. Nema efikasne strategije protiv terorizma koja ne posvećuje pažnju i uzrocima koji dovode do terorizma. Naravno, ostaje pitanje mogu li se u svim slučajevima otkloniti uzroci terorizma i bi li njihovo otklanjanje zaista i dovelo do nestanka terorizma. Bez obzira na negativan odgovor na to pitanje, nemoguće je izbjeći konstataciju da će tako dugo dok postoje političke, ekonomske i socijalne nejednakosti i nepravde i tako dugo dok postoje pojedinci i skupine, koji, u reakciji na takvo stanje, a s ciljem njegova otklanjanja i ostvarenja vlastitih ciljeva tendiraju uporabi nasilja, postojati i terorizam. "Model triju stupova" pruža sveobuhvatan i dubinski uvid $\mathrm{u}$ terorizam. Taj model upozorava na potrebu analize uzroka terorizma, dinamike terorizma kao oblika sukoba, analize odnosa sukobljenih strana i faktora koji utječu na njihove odnose, kao i na okvire rješavanja sukoba. Primjena "modela triju stupova" stoga i jest adekvatan okvir za definiranje sveobuhvatnih i efikasnijih nacionalnih i međunarodnih strategija za borbu protiv terorizma. Primjena teorije rješenja sukoba već je dala pozitivne rezultate u Sjevernoj Irskoj.

\section{ZAKLJUČAK: PREMA TEORIJI TERORIZMA}

Suvremeni svijet još nije našao odgovarajući odgovor na terorizam. Premda je riječ o jednom od najopasnijih političkih, društvenih i sigurnosnih izazova današnjice, terorizam je $u$ svojoj ukupnosti još nedovoljno istražen fenomen. Društveni i politički procesi u međunarodnoj okolini bitno su povećali praktično-teorijske potrebe za izučavanjem terorizma i potaknuli nove interese istraživača. Karakteristika je toga procesa potreba za uvezivanjem uočenih činjenica, usvojenih spoznaja i definiranih zakonitosti, odnosno potreba za sistematiziranjem znanja. Ta bi sistematizacija na teorijskoj osnovi trebala povezati bogatu empiriju terorizma. Drugim riječima, time bi se stvarala teorija terorizma. Taj put nije nimalo lagan, taj zadatak je teško ostvariv, a iz današnje perspektive vrlo je upitno je li uopće ostvariv. No svakako je nadasve vrijedan pokušaja.

Američki politolog Stephen Sloan, čovjek koji akademsku karijeru (Oklahoma University, University of Central Florida) već 40 -ak godina posvećuje istraživanju terorizma i je- 
DRUŠ. ISTRAŽ. ZAGREB GOD. 20 (2011), BR. $3(113)$

STR. $837-859$

BILANDŽIĆ, M. TERORIZAM.. rorizma (Memorial Institute for the Prevention of Terrorism MIPT), osnovanog u spomen na teroristički udar u Oklahoma Cityju 1995., zasigurno je autoritet kada je riječ o raspravama o terorizmu. Njegova stajališta (Sloan, 2008.) kako nejasna međunarodna okolina i globalizacijski nered pogoduju terorizmu u suvremenim uvjetima zaslužuju pažnju. Umjesto ideja o stvaranju "novoga svjetskog poretka" (New World Order), iniciranih na početku 1990-ih, suvremeni svijet suočen je s "novim svjetskim neredom" (New World Disorder). Činjenica o djelovanju 648 terorističkih organizacija u svijetu od 1968., od kojih je njih gotovo 400 u manjem ili većem opsegu još uvijek aktivno, uvjerljivo se uklapa $\mathrm{u}$ iznesena stajališta. Imajući to na umu, napori za daljnjim istraživanjem terorizma i praktičnom primjenom rezultata znanstvenih istraživanja u konkretnim pokušajima razrješenja "terorističkih sukoba" nameću se kao nasušna potreba.

Terorizam je još uvijek općeprihvaćeno generički nedefiniran pojam. Unatoč tome, terorizam je moguće ne samo znanstveno izučavati nego i postojeće teorijske okvire primijeniti na terorizam. Uključivanje elemenata kompenzacijske i posebno kondicionirane moći u buduće protuterorističke strategije potencijalno se čine efikasnim protuterorističkim mjerama. Dosadašnje oslanjanje na silu nije dalo posebnih rezultata u borbi protiv terorizma. U konačnici "teroriziranje terorizma" vodilo je porastu spirale nasilja. U budućim protuterorističkim strategijama stoga je nužno posvetiti pažnju i primjeni koncepta meke moći i eliminiranju uzroka, koji, primjerice, u islamskom svijetu uvjetuju terorizam. Sumarni zaključci raznih teorija sukoba pružaju mogućnosti za utvrđivanje uzroka sukoba koji rezultiraju terorizmom; pružaju mogućnosti za utvrđivanje prirode, odnosno karaktera, sukoba; stvaraju uvjete za oblikovanje modela koji objašnjavaju sukob te pretpostavke za rješenje sukoba. Primjena teorije rješenja sukoba već je dala pozitivne rezultate u Sjevernoj Irskoj. "Model triju stupova" pruža sveobuhvatan i dubinski uvid u terorizam. Taj model upućuje na potrebu analize uzroka terorizma, dinamike terorizma kao oblika sukoba, analize odnosa sukobljenih strana i faktora koji utječu na njihove odnose, kao i na okvire rješavanja sukoba. Primjena "modela triju stupova" stoga i jest adekvatan okvir za definiranje budućih sveobuhvatnih i efikasnijih nacionalnih i međunarodnih strategija za borbu protiv terorizma.

Uz prikazani analitički presjek terorizma $\mathrm{u}$ okvirima niza teorija moći i teorija sukoba, terorizam se može promatrati i kroz druge teorijske okvire, primjerice okvire teorije socijalnog identiteta (Social Identity Theory), teorije socijalnog učenja (Social Learning Theory), teorije sistemskih neprijatelja (Enemy System Theory), frustracijsko-agresivnih teorija (Frustration-Aggression 
DRUŠ. ISTRAŽ. ZAGREB GOD. 20 (2011) BR. $3(113)$

STR. 837-859

BILANDŽIĆ, $M$ TERORIZAM..

\section{BILJEŠKE}

Theory), studija etničkih sukoba (Study of Ethnic Conflict), teorija igara (Game Theory), teorija kaosa (Chaos Theory), teorija kompleksnosti (Complexity Theory), perspektivu javnih politika (Public Policy Perspective), teoriju međunarodnih odnosa (Theory of International Relations), komunikacijske perspektive (Communications Perspective) itd. Sumarni rezultati tih istraživačkih dosega možda su put za razmišljanje o temeljima izgradnje teorije terorizma. Bit će to i putokaz za definiranje "teorije protuterorizma" kao okvira za rješavanje pitanja terorizma, toga sigurnosnog izazova s početka 21. stoljeća, za koji suvremeni svijet nije pronašao odgovarajući odgovor, a čini se da neće ni u predvidivoj budućnosti.

1 U svojoj knjizi Political Terrorism Alex Schmid analizira više od stotinu (109) definicija terorizma. Vidi: Schmid, 1984. Autor ovog rada u svojoj arhivi raspolaže otprilike sa 150 definicija terorizma.

2 Polazeći od shvaćanja britanskoga filozofa Bertranda Russella, Dennis Hume Wrong moć određuje kao sposobnost ljudi da proizvedu namjeravani i očekivani efekt $u$ odnosu na druge ljude. Prema nje$\mathrm{mu}$, konceptualna analiza moći ima pet elemenata: namjeravanost moći, efektivnost moći, latentnost i manifestnost moći, unilateralni ili asimetrični karakter, odnosno asimetričnost i balans u odnosima moći, te karakter efekata koje proizvodi moć. Dennis Wrong razlikuje četiri oblika moći: sila, manipulacija, persuazija i vlast (Wrong, 1988.).

3 PIRA je frakcija IRA-e nastala 1969. nakon raskola unutar republikanskoga pokreta. Od tada je dominantna struja oružanoga dijela republikanskoga pokreta.

4 Oblik kompenzacijske moći jest i amnestija. Riječ je o državnim odlukama kojima se omogućuje uključivanje terorista u civilno društvo, odnosno tranzicija prema civilnom djelovanju (civic action). Akcije iz ovoga spektra ne moraju dovesti do formalnoga sklapanja mirovnoga sporazuma između vlasti i terorističkih organizacija. Teroristima se, naprosto, u zamjenu za odustajanje od nasilja i stanovito kajanje dodjeljuje amnestija i mogućnost uključenja u normalan život. Amnestiju su posebno primjenjivale talijanske vlasti prema pripadnicima Crvenih brigada (tal. Brigate Rosse) 1980-ih godina.

5 O mekoj moći na stanovit način na početku 1990-ih govorio je i Zbigniew Brzezinski. Govoreći o raspadu komunističkoga bloka i kraju Hladnoga rata, iz kojeg je SAD izišao kao pobjednik, Brzezinski je istaknuo da je SAD jedina globalna velesila današnjice. Prema njemu, američka globalna moć temelji se na četiri komponente moći: globalnoj vojnoj moći, globalnom gospodarskom utjecaju, globalnom kulturno-ideološkom utjecaju i globalnom političkom utjecaju, koji je kumulativni rezultat prethodne tri komponente moći (Brzezinski, 1994.).

6 Joseph Nye za meku moć rabi i pojam "strukturalna strana moći" (structural face of power).

7 Izvođenjem terorističkih akata i preuzimanjem odgovornosti za te akte terorističke organizacije skreću pozornost na sebe i svoje ciljeve. 
DRUŠ. ISTRAŽ. ZAGREB GOD. 20 (2011), BR. 3 (113)

STR. $837-859$

BILANDŽIĆ, M. TERORIZAM..
Javnost i publicitet jesu elementi terorizma kao taktike. No kod meke moći ne radi se o ovom aspektu zadobivanja pažnje, nego o zadobivanju pažnje i podrške za svoje ciljeve.

8 Politološka znanost subjektom međunarodnih odnosa određuje svakoga nositelja neke aktivnosti koja utječe na međunarodne odnose $\mathrm{u}$ pozitivnom ili negativnom smislu, pri čemu se kao bitni kriteriji takva određenja navode trajnost djelovanja, svijest da se nešto učini ili ne učini te posljedice koje moraju imati međunarodno značenje (Vukadinović, 1980., 82).

9 Thomas C. Schelling smatra da različite teorije sukoba odgovaraju različitim značenjima riječi sukob. Prema njemu, središnje razlikovanje jest u tome shvaća li se sukob kao patološko stanje, pri čemu se nastoje pronaći razlozi sukoba i načini njegova rješavanja ili se pak sukob prihvaća kao realnost kada je naglasak na proučavanju ponašanja aktera sukoba, što ulazi u područje strategija sukoba. Vidi: Schelling, 2007., 13. Prema Williamu G. Cunninghamu (1998.), postoje dva teorijska pristupa proučavanja sukoba. Na jednoj su strani bihevioristi (mikroteorije), koji pokušavaju objasniti sukob istraživanjem motivacijskih faktora koji dovode do sukoba na razini pojedinca, dok su na drugoj klasični teoretičari sukoba (makroteorije), koji su usredotočeni na istraživanje međusobnoga djelovanja, utjecaja i ponašanja grupa koje su podijeljene po različitim kriterijima: nacionalnom, etničkom, religijskom, klasnom, ideološkom, institucionalnom itd.

10 Fetva je formalni pravorijek o pitanjima islamskoga prava, uputa o rješenju nekoga problema utemeljena na šerijatskom pravu.

11 William Cunningham (2001.) smatra da je "drugom stupu" modela Dennisa Sandolea potrebno dodati i organizacijsku razinu koja je bitna za analizu nasilja terorističkih organizacija.

12 Primjerice, uporabom nasilnih peace-making akcija.

13 Dennis Sandole koristi se pojmovima prevention i provention. Pojam provention preuzeo je od Johna Burtona. Riječ je o svojevrsnom neologizmu koji se u stručnoj literaturi sve više rabi, između ostalog, i kao pokušaj eliminiranja negativnih konotacija koje se ponekad vežu uz pojam prevention. Provention je dugotrajna sustavna promjena sukoba, odnosno institucionalne promjene koje uključuju onemogućavanje budućih sukoba i definitivnu promjenu ranijega stanja koje je dovelo do sukoba. U okvirima rješenja sukoba uključuje uvjete dugotrajne suradnje između ranije sukobljenih strana. Prevention podrazumijeva obuzdavanje sukoba, dok je provention usmjeren na anticipiranje budućih događaja i izbjegavanje sukoba.

14 Dennis Sandole (2004.) odgovor na terorizam promatra kroz tri razine. Razina "simptoma" podrazumijeva odgovor na konkretne terorističke akte. Razina "odnosa" uključuje međugrupne, međukulturne, međuorganizacijske i međudržavne odnose, koji - ovisno o kvaliteti - utječu na "simptome". Razina "duboko ukorijenjenih uzroka" terorizma uvjetovana je pokidanim "odnosima", a time se pojačavaju i "simptomi". Ako se u protuterorističkom djelovanju odgovor usredotočuje prema "simptomima", prema Sandoleu, dolazi do zanemarivanja odgovora na druge dvije razine. 
Azar, E. (1990.), The Management of Protracted Social Conflict: Theory and Cases, Aldershot, Dartmouth.

Bilandžić, M. (2005.), Sjeverna Irska između rata i mira, Zagreb, Golden marketing-Tehnička knjiga.

Bilandžić, M. (2008.a), Al Qa'ida: nastanak, struktura i strategija. Polemos, 11 (1): 33-47.

Bilandžić, M. (2008.b), Islamske oružane organizacije i islamizam na primjeru Bliskog istoka. Revija za sociologiju, XXXIX (4): 307-330.

Brzezinski, Z. (1994.), Izvan kontrole, Zagreb, Otvoreno sveučilište.

Burton, J. W. (2001.), Conflict Provention as a Political System. The International Journal of Peace Studies, 6 (1), prikazano na: http://www. gmu.edu/programs/icar/ijps/vol6_1/Burton2.htm, učitano 15. siječnja 2010.

Cheldelin, S., Druckman, D. i Fast, L. (ur.) (2003.), Conflict: From Analysis to Intervention, London and New York, Continuum.

Coser, A. L. (1969.), The Functions of Social Conflict, New York, The Free Press.

Cunningham, G. W. (1998.), Conflict Theory and the Conflict in Northern Ireland, prikazano na: Conflict Archive on the Internet (CAIN), CAIN Web Service, http://cain.ulst.ac.uk/, učitano 15. siječnja 2001.

Cunningham, G. W. (2001.), Violent Conflict in Northern Ireland: Complex Life at the Edge of Chaos: Chaos, Complexity, and Conflict Resolution Theories, 2001 National Conference on Peacemaking and Conflict Resolution (NCPCR), Research and Education Symposium, June 7-10, 2001, George Mason University, Fairfax, Virginia, prikazano na: Conflict Archive on the Internet (CAIN), CAIN Web Service, http://cain. ulst.ac.uk/, učitano 15. siječnja 2003.

Dougherty, E. J. i Pfaltzgraff, L. R. (1981.), Contending Theories of International Relations, New York, Harper and Row Publishers.

Dugan, L., LaFree, G., Cragin, K. i Kasupski, A. (2008.), Building and Analyzing a Comprehensive Open Source Data Base on Global Terrorist Events, prikazano na: http://www.ncjrs.gov/pdffiles1/nij/grants/223287. pdf, učitano 11. veljače 2009.

Furedi, F. (2009.), Poziv na teror: Rastuće carstvo nepoznatog, Zagreb, Naklada Ljevak

Galbraith, J. K. (1983.), Anatomija moći, Zagreb, Stvarnost.

Gerges, A. F. (2005.), The Far Enemy: Why Jihad Went Global, Cambridge/New York, Cambridge University Press.

Gibbs, J. P. (1989.), Conceptualization of Terrorism. American Sociological Review, 54 (3): 329-340, American Sociological Association, prikazano na: http://people.uncw.edu/ricej/, učitano 18. rujna 2009. doi:10. 2307/2095609

Giddens, A. (2007.), Sociologija, Zagreb, Nakladni zavod Globus.

Gunaratna, R. (2002.), Inside Al Qaeda: Global Network of Terror, New York, Columbia University Press.

Hamad, A. (2007.), U mreži zla: međunarodni terorizam i "Al-Kaida", Banja Luka, Glas Srpske i Una press. 
DRUŠ. ISTRAŽ. ZAGREB GOD. 20 (2011), BR. 3 (113)

STR. $837-859$

BILANDŽIĆ, M.: TERORIZAM..
Haralambos, M. i Holborn, M. (2002.), Sociologija: Teme i perspektive, Zagreb, Golden marketing.

Hudson, A. R. (1999.), The Sociology and Psychology of Terrorism: Who Becomes a Terrorist and Why? A Report Prepared under an Interagency Agreement by the Federal Research Division, Library of Congress, Washington, The Library of Congress.

Jones, G. S. i Libicki, C. M. (2008.), How Terrorist Groups End: Lessons for Countering al Qa'ida, Santa Monica, RAND Corporation.

Kalanj, R. (1994.), Moderno društvo i izazovi razvoja, Zagreb, Hrvatsko sociološko društvo i Zavod za sociologiju Filozofskog fakulteta u Zagrebu.

Klaić, B. (1974.), Veliki rječnik stranih riječi, Zagreb, Zora.

Laqueur, W. (1977.), Terrorism, London, Weidenfeld and Nicholson. Laqueur, W. (1987.), The Age of Terrorism, Boston, Little Brown.

Lindblom, E. C. (1977.), Politics and Markets: The World's PoliticalEconomy System, New York, Basic Books.

Marshall, G. M. (1999.), Third World War: System, Process and Conflict Dynamics, Lanham, Rowman and Littlefield Publishers Inc.

Miall, H., Ramsbotham, O. i Woodhouse, T. (2005.), Contemporary Conflict Resolution: The Prevention, Management and Transformation of Deadly Conflicts, Cambridge, Polity Press.

Muslim Public Opinion on US Policy, Attacks on Civilians and al Qaeda (2007.), prikazano na: http://www.worldpublicopinion.org/pipa/pdf/ apr07/START_Apr07_rpt.pdf, učitano 15. prosinca 2009.

Novalić, F. (2005.), Moć i podčinjavanje. Polemos, 8 (1-2): 239-263.

Nye, J. (2010.), Soft Power and Higher Education, prikazano na: http:// net.educause.edu/ir/library/pdf/ffpiu043.pdf, učitano 5. veljače 2010.

Offman, C. (2007.), Today's Jihadists: Educated, Wealthy and Bent on Killing? National Post, July 3, prikazano na: http://www.nationalpost.com/, učitano 15. kolovoza 2009.

Sageman, M. (2004.), Understanding Terror Network, Philadelphia, University of Pennsylvania Press.

Sandole, D. J. D. i van der Merwe, H. (ur.) (1993.), Conflict Resolution Theory and Practice: Integration and Application, Manchester, Manchester University Press.

Sandole, D. J. D. (1998.), A Comprehensive Mapping of Conflict and Conflict Resolution: A Three Pillar Approach. Peace and Conflict Studies, 5 (2): 1-31, prikazano na: http://www.gmu.edu/programs/icar/ pcs/sandole.htm, učitano 15. siječnja 2010.

Sandole, D. J. D. (2003.), Typology. U: S. Cheldelin, D. Druckman i L. Fast (ur.), Conflict: From Analysis to Intervention (str. 42-57), London and New York, Continuum.

Sandole, D. J. D. (2004.), The 'New' Terrorism: Causes, Conditions and Conflict Resolution, Wiener Blaetter zur Friedensforschung (Vienna Journal in Peace Research), prikazano na: http://icar.gmu.edu/sept11/ article14.pdf, učitano 18. siječnja 2010.

Schelling, C. T. (2007.), Strategija sukoba, Zagreb, Poslovni dnevnik, Masmedia. 
DRUŠ. ISTRAŽ. ZAGREB GOD. 20 (2011) BR. $3(113)$

STR. 837-859

BILANDŽIĆ, $M$ TERORIZAM..
Schmid, P. A. i Jongman, J. A. (1988.), Political Terrorism: A New Guide to Actors, Authors, Concepts, Data Bases, Theories and Literature, Amsterdam, North-Holland Publishing Company.

Schmid, A. (1984.), Political Terrorism: A Research Guide, New Brunswick, TransAction Books.

Sloan, S. (2008.), The Evolution of Terrorism as a Global Test of Wills: A Personal Assessment and Perspective, Oklahoma City, MIPT, Memorial Institute for the Prevention of Terrorism, prikazano na: http://www. mipt.org/, učitano 15. siječnja 2009.

Spencer, A. (2006.), Questioning the Concept of 'New Terrorism', Peace Conflict and Development, 8: 1-33, prikazano na: http://www. peacestudiesjournal.org.uk/, učitano 25. rujna 2007.

Stern, J. (2006.), Terorizam u ime Boga: zašto ubijaju vjerski militanti, Zagreb, Slovo.

Svete, U. (2006.), Strateški značaj informacijsko-komunikacijske tehnologije u suvremenom međunarodnom okolišu. Polemos, 9 (2): 101-117. Townshend, Ch. (2003.), Terorizam, Sarajevo, TKD Šahinpašić.

Turk, A. A. (2004.), Sociology of Terrorism. Annual Review of Sociology, 30 (1): 271-286. doi:10.1146/annurev.soc.30.012703.110510

Vayrynen, T. (2010.), Sharing Reality: An Insight from Phenomenology to John Burton's Problem-Solving Conflict Resolution Theory, Thesis submitted for the degree of Ph.D in International Conflict Analysis University of Kent at Canterbury, prikazano na: http://ethos.bl.uk/, učitano 25. siječnja 2010.

Vukadinović, R. (1980.), Međunarodni politički odnosi, Zagreb, Školska knjiga.

Wrong, H. D. (1988.), Power: Its Forms, Bases, and Uses, Oxford, Basil Blackwell Limited.

\section{Terrorism in Theories and Theoretical Perspectives}

Mirko BILANDŽıć

Faculty of Humanities and Social Sciences, Zagreb

Terrorism is a concept around which the academic, professional, political and wider social circles were not agreed in terms of the generally accepted generic definition. However, for a fuller understanding of terrorism, it is useful to analyze the phenomenon through the prism of theories and theoretical perspectives. This paper presents a series of theories of power and of conflict and their application to terror, terrorism, and terrorist organizations, as well as the relationship between terrorist organizations, as non-state entities, and states. The three pillars model, as a comprehensive theoretical approach to conflict resolution, has an important role in the paper.

Keywords: terrorism, theories of power, soft power, conflict theories, three pillars model, counterterrorism 
DRUŠ. ISTRAŽ. ZAGREB GOD. 20 (2011), BR. 3 (113)

STR. $837-859$

BILANDŽIĆ, M.: TERORIZAM...

\section{Terrorismus. Theorien} und theoretische Perspektiven

Mirko BILANDŽıĆ

Philosophische Fakultät, Zagreb

In wissenschaftlichen und politischen Fachkreisen sowie in der breiteren Öffentlichkeit besteht keine Übereinstimmung hinsichtlich einer allgemein akzeptierten generischen Bestimmung des Terrorismusbegriffs. Dennoch ist es von großem Nutzen, dieses Phänomen vor dem Hintergrund theoretischer Perspektiven zu analysieren, um es besser verstehen zu können. Diese Arbeit bringt eine Übersicht verschiedener Theorien über die Phänomene Macht und Konflikt sowie ihren Bezug zu Terror, Terrorismus, terroristischen Organisationen (im Sinne nichtstaatlicher Entitäten) und Staaten. Das besondere Interesse des Verfassers gilt dem sog. Dreisäulenmodell im Sinne eines umfassenden theoretischen Ansatzes zur Konfliktbeilegung.

Schlüsselbegriffe: Terrorismus, Machttheorien, "weiche” Macht, Konflikttheorien, Dreisäulenmodell, Antiterrorismus 